\title{
HISTOPATHOLOGICAL STUDY OF OVARIAN LUMP AND SERUM TUMOR MARKER CA 125 ESTIMATION AS A SCREENING TOOL
}

\section{Pathology \\ Dr. Durga Nand Jha*}

M.B.B.S, M.D. (Pathology), Tutor, Department Of Pathology, Darbhanga Medical College, Laheriasarai, Bihar. *Corresponding Author

M.B.B.S, M.D. (Pathology), Professor and Head of Department, Department of Pathology, Darbhanga Medical College, Laheriasarai, Bihar.

Young Scientist (DST), Institute of Post-Graduate Medical Education and Research, A.J.C. Bose Road, Kolkata-700020, West Bengal, India.

Dr. Debarshi Jana

\section{ABSTRACT}

BACKGROUND: Ovarian tumor is commonest cancer in female in India. About $80 \%$ is benign and 20\% of these tumors are malignant. Due to its complex nature, vagueness and non-specificity of the symptoms it produces, the ovarian neoplasm can mislead both the doctor and patients. Hence this study was undertaken with aims \& objectives to study the morphology of ovarian specimens as well as estimate serum CA125 as screening tool. MATERIAL AND METHODS: A study of over one year comprised of 75 specimens of ovary diagnosed in the Department of Pathology, Darbhanga Medical College and Hospital, Laheriasarai, Bihar. After thorough gross examination and preparation of H\&E stained slides the lesion of ovary were classified as per WHO classification. Also, preoperative blood samples were obtained from patients for estimation of serum CA125 level. Blood samples was also drawn from 20 healthy females in reproductive age group who acted as controls. RESULTS: Of the 75 cases of ovarian mass, based on histology $75 \%$ were benign, and $25 \%$ were malignant. Surface epithelial tumors were the commonest (68\%) of all ovarian tumor, followed by germ cell tumors (13\%), sex cord-stromal tumors (6\%). Serous Cystadenoma (29\%) was the commonest benign tumor and serous cystadenocarcinoma ( $9 \%$ ) commonest malignant neoplasm. CA125 levels was raised in epithelial ovarian cancers. Maximum rise was seen in serous cystadenocarcinoma. Exceptionally a small percentage of epithelial cancer showed normal level (false negative). Also, few benign tumors, non-epithelial tumors and even non-neoplastic lesions showed false positive rise in CA125 (false positive). CONCLUSION: Accurate histopathological evaluation of ovarian specimen is necessary both in terms of therapeutic intervention as well as prognosis. Ca125 is an important screening tool for detection of epithelial ovarian cancers.

\section{KEYWORDS}

Ovarian Mass, Histopathology, Serum CA125

\section{INTRODUCTION}

The diagnosis of ovarian tumor is very difficult, and mostly delayed, due to the paucity, vagueness and non-specificity of the symptoms it produces. This misleadsboth the doctors and the patient. As it is situated deep in the pelvis, so it becomes inaccessible to clinical examination.

Ovarian tumor is one of the commonest neoplasia in women. Benign tumor of ovary accounts for around $80 \%$ of all ovarian neoplasm and is far more common than malignant counterpart. The risk factors for ovarian malignancy are less well understood than other genital malignancies, although nulliparity, genetic mutations and family history are supposed to be major contributors.

There are multiple tumor markers which are useful in diagnosis, prognosis and for early prediction of recurrence. The important cancer markers are cancer antigen 125 (CA-125), Carcinoembryonic antigen (CEA), Alpha fetoprotein (AFP), \& Beta Human chorionic gonadotrophin (B-HCG).CA 125 hold the position as gold standard in detection and prognosis of the epithelial ovarian cancers whereas $\beta$ HCG and AFP helps in detection and prognosis of germ cell tumor of ovary.

\section{MATERIALAND METHODS}

The present study is based on gross and microscopic evaluation of specimen of ovary received either as solitary specimens, or as part of total abdominal hysterectomy (TAH) from the department of Obstetrics and Gynecology of DarbhangaMedical College and Hospital from November 2019 to October 2020. Fixation of the gross specimens received, was done in $10 \%$ formalin for $12-24$ hours and there after multiple sections were obtained. The sections were prepared by using paraffin technique, microsections of 5 microns thickness were taken onto glass slides and then staining was done by $\mathrm{H}$ $\&$ E stain. Special stains like PAS was reticulin stains were done if found to be necessary.

For the evaluation of screening of tumor marker in these patients, a day before surgery $5 \mathrm{ml}$ of blood was collected from the patients, serum were separated by centrifugation and it was stored for preoperative estimation of CA125. Test was done on a fully automated Chemiluminescence immunoassay analyzer (Siemens Centaur XP) by using commercially available kits. The analyzer automatically calculated and gave the concentration of each sample in IU/L. For quality control we used Bio-Rad standard control $1 \& 2$.

\section{RESULTS}

Histopathological study

75 specimens of ovarian lump were received from the department of obstetrics and gynecology of Darbhanga Medical College and were subsequently examined macroscopically and microscopically.

\section{The observations were made under following headings}

Macroscopic Examination Site of lesion

Noting the relationship of ovary with the site of lesion it was found that 35 cases (46\%) of all ovarian lump arose from left ovary, $33(45 \%)$ arose from right ovary and only $7(9 \%)$ from both the ovaries (shown in table-I).

Table-I : Showing site of lesion of ovarian tumours

\begin{tabular}{|c|c|c|c|c|c|c|}
\hline $\begin{array}{c}\text { No. of } \\
\text { cases }\end{array}$ & $\begin{array}{c}\text { Involvement left ovary } \\
\text { of }\end{array}$ & $\begin{array}{c}\text { Involvement of } \\
\text { Right ovary }\end{array}$ & $\%$ & $\begin{array}{c}\text { Involvement of } \\
\text { both ovary }\end{array}$ & $\%$ \\
\hline 75 & 35 & $46 \%$ & 33 & $44 \%$ & 7 & $9 \%$ \\
\hline
\end{tabular}

\section{Consistency}

Out of 75 cases studied, 56 (74\%) were predominantly cystic and only $19(26 \%)$ cases were predominantly solid ovarian tumors. Among the cystic tumours 27 had serous fluid content, whereas 12 had mucinous. Hemorrhagic and cheesy materials were found in 5 and 12 cases respectively (shown in table-II).

Table-II : Showing incidence of cystic and solidtumours

\begin{tabular}{|c|c|c|c|c|c|c|c|}
\hline \multirow{3}{*}{\begin{tabular}{|c} 
Total \\
No. \\
of \\
cases
\end{tabular}} & \multicolumn{4}{|c|}{ Number of cystic Tumors } & \multirow{3}{*}{\begin{tabular}{|c|}
$\%$ of \\
cystic \\
tumor
\end{tabular}} & \multirow{3}{*}{\begin{tabular}{|c|} 
No. of \\
solid \\
tumor
\end{tabular}} & \multirow{3}{*}{$\begin{array}{c}\% \text { of } \\
\text { solid } \\
\text { tumor }\end{array}$} \\
\hline & Serous & Mucinous & Hemorrhagic & Chessy & & & \\
\hline & fluid & fluid & \& Necrotic & material & & & \\
\hline 75 & 27 & 12 & 5 & 12 & $74 \%$ & 19 & $26 \%$ \\
\hline
\end{tabular}

\section{Microscopic Examination}

Microscopic examination word done on all the 75 cases of ovarian 
mass and they were tabulated according to the histological types.

Table - III : Showing incidence of histological types of ovarian tumors in the classification by WHO

\begin{tabular}{|c|c|c|}
\hline $\begin{array}{l}\text { Histological types of ovarian } \\
\text { tumors }\end{array}$ & $\begin{array}{l}\text { No. of } \\
\text { cases }\end{array}$ & $\begin{array}{l}\text { \% in relation to total } \\
\text { ovarian tumors }\end{array}$ \\
\hline 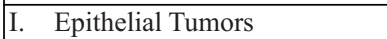 & 51 & 68 \\
\hline A. Serous tumours & 29 & 38 \\
\hline I. Serous cystadenoma & 22 & 29 \\
\hline ii. Serous cystadenocarcinoma & 7 & 9 \\
\hline B. Mucinous Tumors & 16 & 21 \\
\hline $\begin{array}{ll}\text { I. } & \text { Mucinous cystadenoma }\end{array}$ & 13 & 17 \\
\hline $\begin{array}{l}\text { ii. Mucinous } \\
\text { cystadenocarcinoma }\end{array}$ & 3 & 4 \\
\hline C. Endometroid adenocarcinoma & 3 & 5 \\
\hline D. Clear cell tumors & 1 & 1 \\
\hline E. Brenner tumors (benign) & 2 & 3 \\
\hline F. Epithelial Stromal Tumors & Nil & - \\
\hline II. Sex cord/stromal tumors & 4 & 6 \\
\hline A. Granulosa cell tumors & 1 & 1 \\
\hline B. Fibroma & 2 & 3 \\
\hline C. Fibrothecoma & 1 & 1 \\
\hline III. Germ cell tumors & 10 & 13 \\
\hline \begin{tabular}{|l|} 
A. Dysgerminoma \\
\end{tabular} & 2 & 3 \\
\hline B. Dermoid cyst & 6 & 9 \\
\hline C. Yolk sac tumor & 1 & 1 \\
\hline D. Immature Teartoma & 1 & 1 \\
\hline IV. Non-neoplastic cyst & 10 & 13 \\
\hline
\end{tabular}

Form the above table it was observed that epithelial tumors accounted for $68 \%$ of all ovarian tumors. Of them $38 \%$ were serous, $21 \%$ mucinous, $5 \%$ endometriod, $1 \%$ Brenner tumors and $1 \%$ clear cell tumor. The sex cord tumors were $6 \%$ whereas germ cell tumors were found in $13 \%$. Among sex cord tumors, granulose cell tumors were found in $1 \%$ of cases, whereas fibroma and fibrothecoma were present in $3 \%$ and $1 \%$ each respectively. Dysgerminoma and teratoma mature (dermoid cyst) were found 3\% and $9 \%$ respectively and yolk sac and immature teratoma showing $1 \%$ each. Non-neoplastic cysts were seen in $13 \%$ of cases.

\section{Benign and Malignant}

It was observed that out of 75 ovarian masses, $56(75 \%)$ cases were benign and $19(25 \%)$ were malignant.

Table-IV

\begin{tabular}{|c|c|c|c|}
\hline $\begin{array}{c}\text { Total No. of } \\
\text { cases }\end{array}$ & $\begin{array}{c}\text { Benign Tumors } \\
\text { No. cases (\%) }\end{array}$ & $\begin{array}{c}\text { Malignant } \\
\text { Tumors } \\
\text { No. cases (\%) }\end{array}$ & $\begin{array}{c}\text { Ratio between } \\
\text { benign and } \\
\text { malignant }\end{array}$ \\
\hline 75 & $56(75 \%)$ & $19(25 \%)$ & $3: 1$ \\
\hline
\end{tabular}

Table $-\mathrm{V}$ : Showing incidence of various histological of benign ovarian lump

\begin{tabular}{|c|c|c|c|}
\hline Histological types & $\begin{array}{l}\text { No. } \\
\text { of } \\
\text { cases }\end{array}$ & $\begin{array}{l}\% \text { in relation } \\
\text { to benign } \\
\text { tumors }\end{array}$ & \begin{tabular}{|l|}
$\%$ in relation to \\
total ovarian \\
tumors
\end{tabular} \\
\hline $\begin{array}{l}\text { I. Common epithelial tumo } \\
\text { A. Serous cystadenoma } \\
\text { B. Mucinous cystadenoma } \\
\text { C. Brenner tumors }\end{array}$ & $\begin{array}{l}37 \\
22 \\
13 \\
2\end{array}$ & $\begin{array}{l}64 \\
38 \\
23 \\
4\end{array}$ & $\begin{array}{l}46 \\
29 \\
17 \\
3\end{array}$ \\
\hline $\begin{array}{l}\text { II. Sex cord/stromal tumor } \\
\text { A. Fibroma groups } \\
\text { B. Fibrothecoma }\end{array}$ & $\begin{array}{l}3 \\
2 \\
1\end{array}$ & $\begin{array}{l}7 \\
4 \\
2\end{array}$ & $\begin{array}{l}5 \\
3 \\
1\end{array}$ \\
\hline III. Simple cyst & 10 & 18 & 13 \\
\hline $\begin{array}{l}\text { IV. Germ cell tumor } \\
\text { A. Dermoid cyst }\end{array}$ & $\begin{array}{l}6 \\
6\end{array}$ & $\begin{array}{l}10 \\
10\end{array}$ & $\begin{array}{l}8 \\
8\end{array}$ \\
\hline
\end{tabular}

\section{Malignant tumor}

Among 19 cases of malignant tumors, serous cystadenocarcinoma were most common with 7 cases. Next to it was mucinous cystadenocarcinoma 3 cases and endometroid carcinoma 3 cases, followed by dysgerminoma 2 .

Table - VI : Showing incidence of various histological types of malignant ovarian Tumors

\begin{tabular}{|c|c|c|c|}
\hline Histological types & \begin{tabular}{|l|} 
No. \\
of \\
cases
\end{tabular} & \begin{tabular}{|l|}
$\%$ in relation \\
to malignant \\
tumors
\end{tabular} & \begin{tabular}{|l|}
$\%$ in relation \\
to total ovarian \\
tumors
\end{tabular} \\
\hline I. $\quad$ Epithelial Tumors & 14 & 74 & - \\
\hline $\begin{array}{l}\text { A. Serous } \\
\text { cystandenocarcinoma }\end{array}$ & 7 & 37 & 8 \\
\hline B. Mucinous & & & \\
\hline cystandenocarcinoma & 3 & 16 & 4 \\
\hline C. Endometroid tumors & 3 & 16 & \\
\hline D Clear cell & $\begin{array}{l}3 \\
1\end{array}$ & 5 & 1 \\
\hline II. Sex cord/stromal tumors & 1 & 5 & 1 \\
\hline A. Granulos cell tumors & 1 & 5 & 1 \\
\hline III. Germ cell tumors & 4 & 21 & 5 \\
\hline A. Dysgerminoma & 2 & 11 & \\
\hline B. Yolk Sac Tumor & 1 & 5 & 5 \\
\hline C. Immature teratoma & 1 & 5 & \\
\hline
\end{tabular}

\section{Study of CA-125, AFP, $\beta$ hcG as tumor markers}

Serum samples were obtained from 75 patients, who were to undergo surgery for ovarian lump. Serum level values these markers were later correlated with the histopathological diagnosis of the resected specimen. The normal cut off value of CEA, was choosen as $<5 \mathrm{ng} / \mathrm{ml}$, $\mathrm{AFP}$ as $<20 \mathrm{ng} / \mathrm{ml}$ and $\beta$-hcG as $<5 \mathrm{mIu} / \mathrm{ml}$

20 healthy female of different age groups were selected on random basis and were used as control.

Mean values of serum tumor markers level were calculated for each group and the tumor marker concentration was compared with histological types of ovarian tumor.

20 random females in different age groups were to serve as control. 19 out of 20 females serving as control had serum CA1 $125<35 \mathrm{IU} / \mathrm{L}$, one case the result of CA-125-47 IU/L, the blood was collected during her menstrual period.

Considering CA-125 level $<35 \mathrm{IU} / \mathrm{L}$ to be considered as normal, $35-$ $100 \mathrm{IU} / \mathrm{L}$ as insignificant rise, $100-500 \mathrm{IU} / \mathrm{L}$ as significant rise and $>$ 500 as a very high rise of the tumor marker

Substantial rise of CA125 was seen in epithelial ovarian cancers only. $87 \%$ of epithelial tumors shows rise in tumor marker, whereas significant rise (> $100 \mathrm{IU} / \mathrm{L}$ ) was seen in $25 \%$.

Maximum (80\%) sex cord/stromal and germ cell tumor do not shows any rise in CA125, none showing any significant rise ( $>100 \mathrm{IU} / \mathrm{L})$. Almost all of non-neoplastic ovarian mass shows no rise in Ca125.

Out of the Epithelial tumors, highest rise in levels of tumor marker was seen in serous cystadenocarcinoma $\{28 \%$ showing very high levels ( $>500 \mathrm{IU} / \mathrm{L}$ ), $60 \%$ significant rise, none showing normal level $\}$. This was followed by mucinous cystadenocarcinoma \{none showing very high levels $(>500 \mathrm{IU} / \mathrm{L}), 33 \%$ significant rise, one even showing normal level\}. Endometroid and clear cell carcinoma showed rise in levels but did not show a very high levels $(>500 \mathrm{IU} / \mathrm{L}), 66 \%$ of endometroid showing significant rise. $86 \%$ of benign serous and $70 \%$ of mucinous adenoma showed rise in CA125, but none of them showed high levels above $500 \mathrm{IU} / \mathrm{L}$. Significant levels above $100 \mathrm{IU} / \mathrm{L}$ was seen only $8 \%$ of mucinous and $18 \%$ of serous cystadenoma.

\section{DISCUSSION}

Out of 75 cases of ovarian tumors studied, it was recorded that 35 $(46 \%)$ of ovarian tumors arose from left ovary, 33 (44\%) from right ovary and only $7(9 \%)$ from both ovaries (table-I). Bilaterally was mostly observed in serous cystadenocarcinoma. Approximately similar observations were made by Reddy and Rao (1990) who found the involvement of left ovary in $52.5 \%$, right ovary in $42.46 \%$, and both in $5.49 \%$ of cases. In a study conducted by Vaidya et al.and Sharma et al. respectively, bilaterality was found in $8.86 \%$ cases and $11.29 \%$ cases.

In the present series, $56(74 \%)$ were predominantly cystic and 19 $(26 \%)$ were predominantly solid on macroscopic examination. Among 
the cystic tumors 27 had serous fluid content, whereas 12 had mucinous. Hemorrhagic \& cheesy materials were found in 5 and 12 cases respectively (table-II). Gupta SC et al (1986) and Misra RK et al (1990) also had near similar observations.

Of the 75 cases studied in the present series, 56 cases $(75 \%$ turned out to be benign, whereas 19 cases $(25 \%)$ were malignant (table- IV). Couto et al (1993) noted that the incidence of benign tumor was $80 \%$ and the incidence of malignant tumor was $20 \%$. According to Pilli et al (2001) percentage of benign tumor was $76 \%$ and malignant tumor was $24 \%$. The present data seem to be comparable with the figures given by Pilli et al (2001). Whatsoever the variation may be, it is obvious that the incidence of benign tumors is approximately three to four times higher than the malignant one

Comparing the relative percentage of different histological types of ovarian neoplasm with our study and different other studies, it was found that epithelial tumors comprised $68 \%$ of all tumors, followed by germ cell tumors $13 \%$. Sex cord/stromal tumors were found in only $6 \%$ cases. Pilli et al (2001) found epithelial, germ cell and sex tumors in relative percentage of $71 \%, 21 \%$ \& $7 \%$ respectively. Kar et al (2005) found it to be $79 \% .16 \%$ and $1.5 \%$ respectively. Epithelial tumors outnumber all the other neoplasm, a common finding in all the studies.

Serous cystadenomas being the commonest ovarian tumor were present in 22 cases $(29 \%)$ of total ovarian lesions (table-VIII). This is in accordance with Misra RK et al and Maheshwari V et. al reported an incidence of $49 \%$ and $46.01 \%$ of serous cystadenoma. In our study most of the tumors were unilateral and cystic in consistency.

Mucinous cystadenoma accounted for 13 cases (17\%) out of 75 cases of ovarian lesions. Similar findings have been reported by Prabhakar et al $(18 \%)$, Maheshwari et al (13\%). Most of them were cystic in consistency in this study. Bilateral involvement of mucinous cystadenoma was not found in present series. Boyd (1998) reported that bilateral mucinous cystadenoma was relatively uncommon.

Serous cystadenocarcinomas were found to be most common of all malignant ovarian neoplasm, 7 cases $(9 \%)$, followed by mucinous adenocarcinoma 3 cases (4\%). Randhawa et al reported $12 \%$ incidence and Pilli et al reported $3 \%$ for serous cystadenocarcinoma.

Endometroid tumor was seen in 3 cases (4\% of total 75 specimen received). All were found to be malignant. Maheshwari et al in their observation also found that endometroid carcinoma occupies $3.6 \%$ of ovarian neoplasm.

In total, sex cord tumor constituted $6 \%$ of all cases (table-IV) out of which Fibroma was found to be seen most commonly (3\%), a finding similar to Bhattacharjee et.al (1998) and Saxena et.al (1992) who also observed fibroma to be $2 \%$ and $3 \%$ respectively.

The incidence of germ cell tumors was $13 \%$ of all ovarian tumors (table-IV) of which commonest category, Benignteratoma (dermoid cyst) constituted $9 \%$ of cases of total and $46 \%$ of all germ cell tumor. Studies by Gupta SC et al and Couto F et al which showed an incidence of dermoid cyst to be of $23.13 \%, 15.45 \%$ of germ cell tumor respectively. This significant difference might be due to the availability of only a modest number of cases in the present series.

Dysgerminoma was seen in 3\% of all cases under study. Studies by Gupta SC et aland Couto F et al showed an incidence of 3.5 and 2.9 respectively which is in accordance to our study.

\section{Serum Tumor markers Ca125}

The important cancer markers for Ovarian cancers are: cancer antigen 125 (CA-125), Carcinoembryonic antigen (CEA), Alpha fetoprotein (AFP), \& Beta Human chorionic gonadotrophin (B- HCG) of which CA125 holds the position of gold standard in detection as well as a prognostic marker of ovarian cancers.

Based on our study, CA125 rises in epithelial ovarian cancers and maximum rise is seen in serous cystadenocarcinoma. Similar observation was seen in a study by Mehboob S. et al. In our study, a very high rise of CA125, much above $500 \mathrm{IU} / \mathrm{L}$ was seen in serous cystadenocarcinoma only. alone. Rise in level specially in the range of $35-100 \mathrm{IU} / \mathrm{L}$ were seen in both non-epithelial neoplasm and non-neoplastic ovarian mass. But all these did not show very high level of tumor marker. Hence, this tumor marker is not specific for epithelial ovarian carcinomas alone. Although high levels almost always suggest epithelial carcinoma.

Not all epithelial ovarian cancers show a rise in CA125. One case of mucinous cystadenocarcinoma showed a normal level $(<35 \mathrm{IU} / \mathrm{L})$. This lack of specificity and sensitivity is in accordance with study by Buamah, P., 2000.

\section{CONCLUSION}

An accurate histopathological diagnosis along with clinical staging can help in understanding of ovarian tumorigenesis and proper management.

CA 125 is an important tumor marker for early diagnosis of the epithelial ovarian cancer, although the test like all other tumor markers do have limitations.

\section{REFERENCES}

1. Azizs, Kuperstein G, Rosen B, Cole D, Nedelew R, Mclaughlin J, Narod SA et al. A genetic epidemiologic study of carcinomar of the fallopian tube, Gyncologic oncology. 80:341 (2001).

2. Buamah, P. 2000. Benign conditions associated with raised serum CA125 concentration. J. Surg Oncol. 75264-265.

Couto F, Nadkarni NS, Rebello MJ. Ovarian Tumours in Goa-A clinicopathological study. Journal of Obstetrics and Gynaecology of India 43:3 (1993) 40812

4. Faisal B L, Muhammad A. Riaz H. Serum Tumor Markers, Professional Med J March Faisal B L, Muha.

5. Ganga S Pilli, K.P.Sunitha, A.V.Dhaded, V V.Yenni. Ovarian tumors a study of 282 cases. J Indian Med Associ; 100:7 (2002) 420-424.

6. Gupta D and Christopher GL. Role of CA 125 in predicting ovarian cancer survival. J o Ovarian Research 2:13 (2009) 1757-2215.

7. Gupta SC, Singh PA, Mehrotra TN, Agarwal R. Indian J Pathol. Microbiol 29 (1986) 354-362.

8. Maheshwari V, Tyagi SP, Saxena K. Surface epithelial tumors of ovary. Indian J PatholMicrobiol 37:10 (1994) 75-85

9. Mani R, Jamil K and Moharia CV, Specificity of serum tumor markers (CA125, CEA, AFP, Beta HCG) in ovarian malignancies. Trend Med Res: 2:3 (2007)128-134

10. Mankar DV, Jain GK. Histopathological profile of ovarian tumours: A twelve yea institutional experience. Muller J Med Sci Res. 6:2 (2015)107-11

11. Mehboob S, Ghafoor F, Yunus S, Sajjad R. Role of CA-125 as an Ovarian Tumor Marker Pak J Med Res, 48:3 (2009).

12. Misra RK, Sharma SP, Gupta U, Gaur R, Misra SD, Pattern of ovarian neoplasm in eastern U.P. Journal of obstetrics and Gynaecology 41:2 (1990) 242-246.

13. Narod SA, Boyd J. Current understanding of the epidemiology, and clinical implication of BRCA1 and BRCA2 mutation for ovarian cancer. Current Opinion in obstetric and Gynecology. 14:19(2002)

14. Novak. Gynaecologic and obstetric pathology with clinical and endocrine relation. 8th ed. W.B.: saunders company. 1979

15. Prabhakar BR, Kalyani M. Ovarian tumors-prevalence in Punjab. Indian J. Pathol.Microbiol 32:4 (1989) 276281.

16. Randhawa I, Lata P. A study of ovarian neoplasm. J. Obstet .Gynec. India 1980; 30:531535

17. Vaidya S, Sharma P, KC S, VaidyaSA. Spectrum of ovarian tumor in a referral hospital in Nepal. Journal of Pathology Nepal.14 (2014) 539-543.

18. Young RH, The ovary. In: Sternberg S. diagnostic Surgical Pathology. 17th Ed. New York: Raven Press; 1994. p. 2195 